\title{
Mercury Exposure: Protein Biomarkers of Mercury Exposure in Jaraqui Fish from the Amazon Region
}

\author{
José Cavalcante Souza Vieira ${ }^{1}$ Camila Pereira Braga ${ }^{1}$ (D) $\cdot$ Grasieli de Oliveira $^{1}$. \\ Cilene do Carmo Federici Padilha ${ }^{1}$ - Paula Martin de Moraes ${ }^{1}$ Luiz Fabricio Zara ${ }^{2}$. \\ Aline de Lima Leite $^{3} \cdot$ Marília Afonso Rabelo Buzalaf ${ }^{3}$. Pedro de Magalhães Padilha ${ }^{1}$
}

Received: 10 April 2017 / Accepted: 10 August 2017 /Published online: 21 August 2017

(C) Springer Science+Business Media, LLC 2017

\begin{abstract}
This study presents data on the extraction and characterization of proteins associated with mercury in the muscle and liver tissues of jaraqui (Semaprochilodus spp.) from the Madeira River in the Brazilian Amazon. Protein fractionation was carried out by two-dimensional electrophoresis (2D-PAGE). Mercury determination in tissues, pellets, and protein spots was performed by graphite furnace atomic absorption spectrometry (GFAAS). Proteins in the spots that showed mercury were characterized by electrospray ionization tandem mass spectrometry (ESIMS/MS). The highest mercury concentrations were found in liver tissues and pellets ( $426 \pm 6$ and $277 \pm 4 \mu \mathrm{g} \mathrm{kg}^{-1}$ ), followed by muscle tissues and pellets $(132 \pm 4$ and $86 \pm 1 \mu \mathrm{g} \mathrm{kg}^{-1}$, respectively). Mercury quantification in the protein spots allowed us to propose stoichiometric ratios in the range of 1-4 mercury atoms per molecule of protein in the protein spots. The proteins characterized in the analysis by ESI-MS/MS were keratin, type II cytoskeletal 8, parvalbumin beta, parvalbumin-2, ubiquitin40S ribosomal S27a, 39S ribosomal protein L36 mitochondrial, hemoglobin subunit beta, and hemoglobin subunit beta-A/B. The results suggest that proteins such as ubiquitin-40S ribosomal protein S27a, which have
\end{abstract}

Camila Pereira Braga

braga_ca@ibb.unesp.br

1 Institute of Bioscience of Botucatu, São Paulo State University (UNESP), Rubião Júnior, Botucatu, São Paulo 18618-970, Brazil

2 Pontifical Catholic University of Goiás (PUC), Goiânia, GO, Brazil

3 Bauru Dental School, University of São Paulo-USP, Bauru, SP, Brazil specific domains, possibly zinc finger, can be used as biomarkers of mercury, whereas mercury and zinc present characteristics of soft acids.

Keywords Mercury in fish · Biomarkers of mercury exposure $\cdot$ Metallomics study $\cdot 2 \mathrm{D}-\mathrm{PAGE} \cdot \mathrm{ESI}-\mathrm{MS} / \mathrm{MS}$

\section{Introduction}

Amazonian Rivers suffered a major invasion of gold miners in the past decades and, as a result, large amount of mercury was poured into riverbeds and lakes, increasing its concentration [1]. The aquatic environment and its biotic population already receive a load of this toxic metal naturally through geochemical processes such as wearing of rocks and through human activities such as metal production, industrial activities, the burning of fossil fuels, agriculture and extraction activities, and smelting of ores in gold mining operations [1-3].

However, over the past 5 years, with the implementation of hydroelectric plants in the Amazon Rivers, mercurial species hitherto inert in the sediments have been made available to the water column [4-7]. The damming of the river, necessary for the construction of hydroelectric power plants, can promote the transformation of available mercury in inorganic form into organic forms such as methylmercury, which is a highly toxic species that bioaccumulates in living organisms $[3,6,8,9]$.

Mercury can accumulate in tissues and organs of aquatic organisms at concentrations higher than those found in water $[10,11]$. In humans, it is able to pass through biological membranes of the mother to the fetus, causing anatomical abnormalities and severe damage to the central nervous system $[2,8,12,13]$. High concentrations of mercury in rodents and humans can cause hepatotoxicity, nephrotoxicity, and neurological damage $[8,14]$. Experiments with rodents 
exposed to organic or inorganic forms of mercury have shown permanent damage to the central nervous system, kidneys, lungs, and immune system, as well as mutagenic, carcinogenic, and teratogenic effects [8].

A large portion of the Amazon population, beleaguered in cities like Manaus, Belém, Porto Velho, and communities scattered along the banks of rivers, live mainly on fishing activities [15-17], increasing the concern about mercury contamination, which can cause irreversible damage to people who consume fish as their primary source of animal protein $[9,15]$. The negative impact of mercury on human health has motivated its monitoring in many parts of the world, including studies to evaluate its concentration in the muscle, liver, and kidneys of fish, considering the increase in fish consumption by much of the population in recent decades [14].

Among the fish species most consumed by the Brazilian Amazon population, the following stand out: dourada (Brachyplatystoma rousseauxii), tucunaré (Cichla spp.), filhote (Brachyplathystoma filamentosum), jatuarana (Brycon spp.), curimatã (Vimboides Prochilodos), pacu (Mylossoma spp. Myleus), and jaraqui (Semaprochilodus spp.), among others. The jaraqui (Semaprochilodus spp.) is a medium-sized fish that reaches a maximum size of 24-30 cm and is much appreciated and consumed by the Brazilian Amazon population. The jaraqui has a benthopelagic habit and features great mobile lips with several rows of sickle teeth, which allow it to "scrape" organic matter from various surfaces. So much of their diet is detritivores, as they feed on microorganisms associated with sediment and algae, which can favor the absorption of mercurial species in the sediment. In the Amazon region, at popular prices, the species is easily found in all fairs, markets, and restaurants [5, 7, 15].

Based on the above, the objective of this study was to study the muscle and liver samples of jaraqui (Semaprochilodus spp.) collected in the area of influence of the Jirau hydroelectric plant on the Madeira River using a metalloproteomic strategy to identify possible biomarker proteins of mercury exposure.

\section{Material and Methods}

\section{Sample Collection and Analysis}

A total of seven individuals from this species with a median length of $40 \pm 8 \mathrm{~cm}$ and an average weight of $700 \pm 15 \mathrm{~g}$ were collected in 2015 (considering the regional seasonality of full, flood, ebb, and dry) from the Jirau hydroelectric power plant in the Madeira River basin located in the state of Rondonia/ Brazil (lat S 9 $15^{\prime} 17.96^{\prime \prime}$ and long W 64 38' 40.13"). After the fish were caught, they were anesthetized with a benzocaine solution $\left(100 \mathrm{mg} \mathrm{L}^{-1}\right)$ and euthanized to collect samples of muscle and liver tissue. Tissue samples (muscle and liver) were fragmented with a scalpel into pieces of approximately
$1 \mathrm{~cm}$, placed in $25 \mathrm{~mL}$ polypropylene flasks, and stored in a freezer at $-80{ }^{\circ} \mathrm{C}$ until analysis. Pools of each tissue were homogenized using liquid nitrogen, weighed to approximately $2 \mathrm{~g}$, and macerated with $2 \mathrm{~mL}$ of ultrapure water. The protein extracts were separated from the solid fraction by centrifugation at $13,000 \mathrm{~g}$ at $4{ }^{\circ} \mathrm{C}$ in two sessions of $20 \mathrm{~min}$ each. The supernatants obtained (protein extracts) were transferred to $2 \mathrm{~mL}$ tubes and subjected to fractional precipitation to obtain protein pellets of higher and lower molecular weight.

The pellets were obtained by fractional precipitation using two steps $[5,7,17,18]$. In the first precipitation step, ethanolchloroform solution aliquots $(1: 1 v / v)$ were added to the protein extract in microtubes at a ratio of $1: 1(v / v)$ and kept in the freezer for $15 \mathrm{~min}$, followed by centrifugation at $10,000 \mathrm{rpm}$ at $4{ }^{\circ} \mathrm{C}$ for $15 \mathrm{~min}$. The precipitates obtained in this step (pelleted protein of molecular mass $>90 \mathrm{kDa}$ ) were used for determination of total mercury content, and the supernatants were used for obtaining the pelleted protein of lower molecular mass $(<90 \mathrm{kDa})$. In the second precipitation step, aliquots of $400 \mathrm{uL}$ of ethanol/ hydrochloric acid solution $(2.5: 1 \mathrm{v} / \mathrm{v})$ were added to $1 \mathrm{~mL}$ of the supernatant obtained in the first precipitation step and the rest kept in the freezer at $-20^{\circ} \mathrm{C}$ for $120 \mathrm{~min}$. Then, the solid fraction (pelleted protein) was separated from the liquid fraction by centrifugation at $10,000 \mathrm{rpm}$ and $4{ }^{\circ} \mathrm{C}$ for $15 \mathrm{~min}$. The supernatant was discarded and the protein pellets obtained (molecular weight $<90 \mathrm{kDa})$ were washed with cold ethanol $\left(-20^{\circ} \mathrm{C}\right)$ to remove acid residues. This procedure was performed in triplicate $(n=3)$ for quantification of total protein, 2D-PAGE electrophoretic runs, and determination of total mercury in the muscle and liver tissues, pellets, and protein spots by GFAAS after acid mineralization of the samples $[5,7,17,18]$.

\section{Protein Fractionation by 2D-PAGE}

Protein fractionation by two-dimensional electrophoresis (2DPAGE) was carried out on the pellets containing lower molecular weight $(<90 \mathrm{kDa})$ proteins for both tissue pools (muscle and liver). A total of 18 gels were made, in this case, 9 gels for each tissue pool. The protein pellets were solubilized in a solution containing $7 \mathrm{~mol} \mathrm{~L}^{-1}$ urea, $2 \mathrm{~mol} \mathrm{~L}^{-1}$ thiourea, $2 \%(\mathrm{~m} / \mathrm{v})$ CHAPS, $10-0.5 \%(v / v)$ ampholytes at $\mathrm{pH} 3-10$, and $0.002 \%$ bromophenol blue. In addition, $50 \mathrm{~mol} \mathrm{~L}^{-1}$ DTT were added to this solution, and this mixture was used for 2DPAGE separations. The electrophoretic runs were carried out using 13-cm strips containing pre-made gel with immobilized ampholytes in the $\mathrm{pH}$ range from 3 to 10 . Each strip was hydrated with a solution containing $1.5 \mathrm{mg} \mathrm{mL}^{-1}$ of protein for a period of $12 \mathrm{~h}$. The proteins in the hydrated strips were then fractionated in the first dimension using the Ettan IPGphor 3 Isoelectric Focusing (IEF) system, which separates the proteins according to their pI (isoelectric point). After fractionation of the proteins by IEF, the strips were equilibrated in two steps, using two solutions. In the first step, $10 \mathrm{~mL}$ of 
solution containing $6 \mathrm{~mol} \mathrm{~L}^{-1}$ urea, $2 \%(w / v) \mathrm{SDS}, 30 \%(v / v)$ glycerol, $50 \mathrm{mmol} \mathrm{L}{ }^{-1}$ Tris- $\mathrm{HCl}(\mathrm{pH} 8.8), 0.002 \%(w / v)$ bromophenol blue, and 2\% (w/v) DTT was used in order to maintain proteins in their reduced forms. In the second stage, we used a solution of similar composition, replacing the DTT by iodoacetamide at $2.5 \%(\mathrm{w} / \mathrm{v})$ to promote alkylation of the thiol groups of the proteins and thus prevent possible re-oxidation. The two phases were maintained under stirring for a period of $15 \mathrm{~min}$ each. Then, the strips were placed on $15 \%$ $(w / v)$ polyacrylamide gels, with 14-97 kDa molecular mass standards added alongside each gel, which were then placed in the electrophoresis system. After the systems were sealed with $0.50 \%(w / v)$ agarose solution, the 2D-PAGE runs were started. After the run, which lasted $270 \mathrm{~min}$, the proteins were revealed using a colloidal Coomassie stain reagent composed of ammonium sulfate $8 \%(w / v)$, phosphoric acid $1.6(v / v)$, and Coomassie blue G-250 $0.08 \%(w / v)$. Before staining, the proteins were fixed for $60 \mathrm{~min}$ using a solution containing acetic acid $10 \%(v / v)$ and ethanol $40 \%(v / v)$. The dye was allowed to remain in contact with the gel for $72 \mathrm{~h}$, after which it was removed through successive washes with ultrapure water, digitized, and analyzed using the ImageMaster software Platinum version 7.0 to obtain the number of spots, percentage correlation between the gels, pI, and molecular mass of the spots [5, $7,16,18]$. Three runs per tissue were performed in duplicate to quantify the $\mathrm{Hg}$ and one run in triplicate for characterization of pelleted proteins with molecular mass $<90 \mathrm{kDa}[7,17]$.

\section{Mercury Determinations}

Mercury determinations were performed on samples of muscle and liver tissue of jaraqui in the protein pellets and protein spots by atomic absorption spectrometry graphite furnace (GFAAS) after acid mineralization of samples according to the procedure optimized by Moraes et al. [6]. The validation of the analytical method used was carried out using certified standard Fish Protein DORM-4-NRC containing $410 \pm 55 \mathrm{\mu g} \mathrm{kg}^{-1}$ of total mercury, and the concentration obtained by GFAAS was $403 \pm 12 \mu \mathrm{g} \mathrm{kg}^{-1}$.

\section{Characterization of Protein Spots by ESI-MS/MS}

The proteins in the protein spots that showed mercury in mercury determinations by GFAAS were characterized by electrospray ionization tandem mass spectrometry (ESI-MS/MS) after tryptic digest according to the procedure described in the Technical Bulletin of Walters [7, 17]. In brief, the steps are dye removal, reduction and alkylation, tryptic digestion, and elution of peptides. The reverse column (nanoAcquity UPLCR - nanoAcquity HSS T3) was equilibrated with mobile phase A $(0.1 \%$ formic acid in water). Peptides were separated with a linear gradient of $7-85 \%$ mobile phase B $(0.1 \%$ formic acid in ACN). Positive mode was used in XevoR G2 Q-TOF mass, and data were collected at elevated energy (19-45 V). Data acquisition was obtained over $20 \mathrm{~min}$, and the scan range was 50-2000 Da. ProteinLynx Global Server (PLGS) version 3.0 was used to process and search the continuum LC-MSE data, setting carbamidomethylation of cysteines as fixed modification and oxidation of methionines as variable modification, allowing one missing cleavage and maximal error tolerance of $10 \mathrm{ppm}$. The proteins were identified by the embedded ion accounting algorithm of the software and by searching the Otophysi database.

\section{Results and Discussion}

\section{Protein Fractionation by 2D-PAGE}

The total protein concentrations in pellets were $17.80 \pm 0.45$ and $11.70 \pm 0.25 \mathrm{~g} \mathrm{~L}^{-1}$ for liver and muscle tissue, respectively.

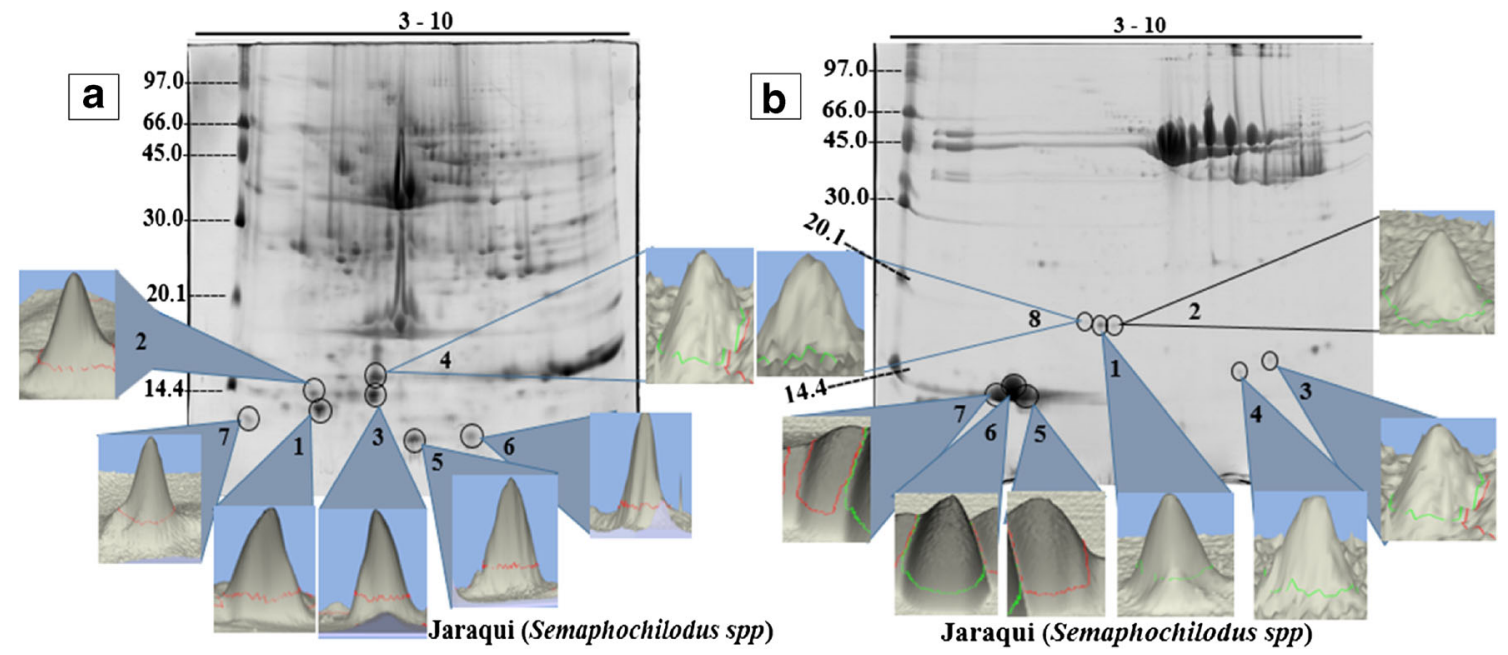

Fig. 1 Gel 15\% (w/v) obtained by 2D-PAGE (pH range 3-10) to the liver (a) and muscle (b) of jaraqui. The numbers and circles indicate the protein spots where $\mathrm{Hg}$ was identified and proteins characterized by ESI-MS/MS 
Table 1 Values obtained in the determination of the mercury in lower molecular weight protein pellets $(<\mathrm{Mm})$ and higher molecular weight protein pellets $(>\mathrm{Mm})$, present in the jaraqui muscle $(\mathrm{JM})$ and liver $(\mathrm{JL})$ samples

\begin{tabular}{llllllll}
\hline & JM pellets $(>\mathrm{Mm})$ & JL pellets $(>\mathrm{Mm})$ & JM pellets $(<\mathrm{Mm})$ & JL pellets $(<\mathrm{Mm})$ & Muscle & Liver $^{\text {DORM-4-NRC }}$ \\
\hline Jaraqui & ND & ND & $86 \pm 1$ & $277 \pm 4$ & $132 \pm 4$ & $426 \pm 6$ \\
Certified standard & - & - & - & - & - & - & $403 \pm 12$ \\
\hline
\end{tabular}

Mercury concentrations expressed in $\mu \mathrm{g} \mathrm{kg}^{-1}$

$N D$ not detect

${ }^{\mathrm{a}}$ Certified standard of fish muscle protein containing $410 \pm 55 \mu \mathrm{g} \mathrm{kg}^{-1}$

Using these concentrations, a mass of $375 \mu \mathrm{g}$ protein was applied to each strip, following the guidelines of the IEF equipment protocol for better separation of proteins in strips at $\mathrm{pH} 3-10[5,7]$.

After the protein spots were visualized in the gels, as previously described, images were aligned using the software ImageMaster Platinum, version 7.0, showing similarity between the four runs of $82 \pm 3$ and $75 \pm 2 \%$ for liver and muscle tissue, respectively. This indicates a good repeatability and reproducibility for the replicate gels. The protein spots that presented mercury (Fig. 1a, b) were characterized by ESI-MS/MS.

\section{Determination of Total Mercury}

The total mercury was determined directly into liver and muscle tissues as well as in the protein pellets with molecular mass $>90$ and $<90 \mathrm{kDa}$. The certified standard DORM-4-NRC was used to validate the method of determination of mercury [6].
The limits of detection (LOD) and quantification (LOQ) of the determination method, calculated based on the standard deviation of 10 readings of the standard solution blank and on the slope of the analytical curve (LOD $=3$ /slope and $\mathrm{LOQ}=10 /$ slope), were 0.017 and $0.054 \mu \mathrm{g} \mathrm{L}^{-1}$ mercury, respectively. The (LOD) and (LOQ) determined in relation to the certified standard, using $0.01 \mathrm{~g}$ of DORM-4-NRC, were 0.04 and $0.10 \mu \mathrm{g} \mathrm{kg}^{-1}$, respectively [6, 19]. The results are shown in Table 1.

As shown in Table 1, mercury was not detected in the pelleted proteins of molecular weight $>90 \mathrm{kDa}$, whereas the pelleted proteins of molecular weight $<90 \mathrm{kDa}$ showed $426 \pm 6$ and $132 \pm 4 \mu \mathrm{g} \mathrm{kg}^{-1}$ of mercury for liver and muscle tissue, respectively. This can occur because mercury preferentially binds low-molecular-weight proteins that may contain active sites with sulfur atoms, such as metallothioneins [3, 20, 21]. When the amount of mercury found in liver and muscle tissues was compared with that in their respective pellets, there was a loss during the extraction process of approximately $35 \%$

Table 2 Values for $\mathrm{Hg}$ concentration determined by GFAAS and estimated number of $\mathrm{Hg}$ atoms per molecule in the protein spots for jaraqui muscle (JM) and liver (JL)

\begin{tabular}{|c|c|c|c|c|c|c|c|}
\hline $\begin{array}{l}\text { Protein } \\
\text { spots }\end{array}$ & $\begin{array}{l}\text { Molecular } \\
\text { weight }(\mathrm{kDa})\end{array}$ & $\mathrm{pI}$ & $\begin{array}{l}\text { Protein } \\
\text { mass }(g)\end{array}$ & $\begin{array}{l}\text { Concentration of } \\
\mathrm{Hg}\left(\mathrm{mg} \mathrm{g}^{-1}\right)\end{array}$ & $\begin{array}{l}\text { Number of molecules in } \\
\text { the protein spot }\left(10^{13}\right)\end{array}$ & $\begin{array}{l}\text { Number of } \mathrm{Hg} \\
\text { atoms }\left(10^{13}\right)\end{array}$ & $\begin{array}{l}\text { Number of } \mathrm{Hg} \text { atoms } \\
\text { per protein molecule }\end{array}$ \\
\hline JL1 & 13.00 & 4.10 & 0.90 & 25.80 & 4.00 & 7.00 & 1.70 \\
\hline JL2 & 13.80 & 4.10 & 2.10 & 27.10 & 9.00 & 17.00 & 1.90 \\
\hline JL3 & 13.60 & 5.30 & 9.50 & 28.30 & 42.00 & 81.00 & 1.93 \\
\hline JL4 & 14.60 & 5.60 & 8.50 & 12.90 & 35.00 & 33.00 & 0.94 \\
\hline JL5 & 11.50 & 6.10 & 5.80 & 35.00 & 30.00 & 61.00 & 2.03 \\
\hline JL6 & 11.60 & 7.20 & 2.10 & 51.00 & 11.00 & 32.00 & 2.91 \\
\hline JL7 & 12.50 & 3.10 & 1.90 & 14.00 & 9.00 & 8.00 & 0.90 \\
\hline JM1 & 17.00 & 6.00 & 1.00 & 12.00 & 36.00 & 37.00 & 1.03 \\
\hline JM2 & 17.00 & 6.20 & 0.30 & 12.20 & 10.00 & 11.00 & 1.00 \\
\hline JM3 & 14.80 & 8.90 & 0.30 & 13.30 & 13.00 & 12.00 & 0.93 \\
\hline JM4 & 14.10 & 8.30 & 0.20 & 29.20 & 9.00 & 17.00 & 1.90 \\
\hline JM5 & 12.80 & 4.70 & 7.80 & 63.20 & 3.70 & 14.60 & 3.95 \\
\hline JM6 & 12.90 & 4.50 & 39.30 & 47.40 & 190.00 & 560.00 & 2.90 \\
\hline JM7 & 12.80 & 4.20 & 4.80 & 63.60 & 230.00 & 916.00 & 3.99 \\
\hline JM8 & 17.30 & 5.70 & 0.14 & 11.40 & 4.00 & 5.00 & 1.20 \\
\hline
\end{tabular}

$J L$ jaraqui liver, $J M$ jaraqui muscle, $p I$ isoeletric point 
in liver pellets and $37 \%$ in muscle pellets; this can be explained by the binding of mercury to lipids and/or other macromolecules, which are discarded during the extraction process or lost in the sample handling process $[17,22]$. Mercury was also quantified in the protein spots obtained by 2D-PAGE. Table 2 shows the molecular masses $(\mathrm{Mm})$ and isoelectric points (pI) of the protein spots, the protein mass in these spots calculated using the ImageMaster software platinum version 7.0, mercury concentrations determined in each spot, and the number of protein molecules and of mercury atoms in the protein spots. As shown in Table 2, mercury concentrations in the spots were in the range of 12.90 $51.00 \mathrm{mg} \mathrm{g}^{-1}$ and $11.40-63.60$ for liver and muscle tissue, respectively. Based on the mercury concentration in each protein spot of liver, a stoichiometric correlation was done to estimate the number of mercury atoms per protein molecule $[17,22]$. The estimates of stoichiometric ratios indicated that the protein spots have approximately $1-4$ mercury atoms per protein molecule, indicating that there may be a stoichiometric ratio. If so, it can be inferred that the proteins of these spots will be metalloproteins and/or metal-binding proteins. These results corroborate the findings of Braga et al. (2015) and Vieira et al. (2015) [7, 17], who proposed a stoichiometric ratio considering mercury concentration and protein mass in protein spots of dourada and tucunaré of the Amazon region $[17,22]$.

The protein spots that showed mercury (Fig. 1) were characterized by ESI-MS/MS. Analysis by ESI-MS/MS allowed the characterization of five proteins in the protein spots of muscle and liver tissue of jaraqui (Tables 3 and 4).

\section{Hemoglobin Subunit Beta}

The hemoglobin subunit beta is a protein involved in transporting oxygen from the gills to the various peripheral tissues of fish [23]. This protein was characterized by mass spectrometry ESI-MS/MS in protein spots JM1 and JM3 muscle tissue of jaraqui, and these same spots showed mercury ( 25.80 and $28.30 \mathrm{mg} \mathrm{g}^{-1}$, respectively) in the analysis by graphite furnace atomic absorption spectrometry. Hemoglobin has been considered as a protein associated with metals, and the cysteine residue found in a $\beta$-chain could possibly be the primary site for mercury binding. This suggests that $\mathrm{Hb}$ may act as a protein that binds to mercury in fish, being a potential carrier of this element of the blood to the liver, kidneys, muscles, and other organs of the body [23]. A study by Park and Lee [24] showed hemoglobin levels in relation to the concentration of toxic metals in the body and their interactions with other tissues, corroborating our results [24, 25]. Analysis of liver tissue from dolphins (Lagenorhynchus acutus) also revealed hemoglobin as a protein that binds to mercury $[23,24]$. When the stoichiometric ratio was estimated, considering the number of $\mathrm{Hg}$ atoms per protein molecule 
Table 4 Proteins identified by ESI-MS/MS in jaraqui liver

\begin{tabular}{|c|c|c|c|c|c|c|c|}
\hline Spot & Protein & Accession & Score & $\begin{array}{l}\text { Spot pI/Mw } \\
(\mathrm{kDa})\end{array}$ & $\begin{array}{l}\text { Theoretical } \\
\text { pI/Mw (Da) }\end{array}$ & $\begin{array}{l}\text { Coverage } \\
(\%)\end{array}$ & Sequenced peptides \\
\hline JL1 & Parvalbumin beta & PRVB_SQUCE & 48.5226 & $4.10 / 13.00$ & 11.30 & 9.43 & SGFIEEEELK \\
\hline JL2 & Parvalbumin-2 & PRV2_DANRE & 47.7782 & $4.10 / 13.80$ & 11.60 & 10.09 & LFLQNFSAGAR \\
\hline JL5 & $\begin{array}{l}\text { Ubiquitin-40S ribosomal } \\
\text { protein } \mathrm{S} 27 \mathrm{a}\end{array}$ & RS27A_ICTPU & 126.013 & $6.10 / 11.50$ & 18.00 & 5.77 & ESTLHLVLR GGAKK \\
\hline JL6 & Keratin, type II cytoskeletal 8 & K2C8_DANRE & 745.119 & $7.20 / 11.60$ & 57.80 & 2.12 & LALDIEIATYR \\
\hline JL7 & $\begin{array}{l}\text { 39S ribosomal protein L36. } \\
\text { mitochondrial }\end{array}$ & RM36_DANRE & 50.9635 & $3.10 / 12.50$ & 12.94 & 11.21 & SLVGSLTR SALKK \\
\hline
\end{tabular}

found in the spot, there was a ratio of approximately $1 \mathrm{Hg}$ atom per hemoglobin subunit beta molecule. This protein, in addition to being a metalloprotein, already has a history of binding to toxic metals such as mercury and may thus become an important biomarker of this metal in fish.

\section{Parvalbumin}

The parvalbumin and its isoforms (parvalbumin-2 alpha and beta) is a metalloproteinase that binds calcium and magnesium ions and can be found in the brain, kidney, muscle, and liver, exerting functions in signal transduction, muscle contraction, and relaxation $[26,27]$. Previous studies by our group in the Madeira River with the fish species Cichla spp. and B. rousseauxii found that protein was bound to $\mathrm{Hg}$ at a stoichiometric ratio of approximately 1 atom of mercury per molecule of protein, both in the liver and in the muscle [7, 17]. In jaraqui (Semaprochilodus spp.), parvalbumin isoforms were found in the JL1 and JL2 spots from liver tissue at a stoichiometric ratio of 2 atoms $\mathrm{Hg}$ per protein molecule and in JM5 and JM6-7 spots from muscle tissue at a stoichiometric ratio of 4 atoms $\mathrm{Hg}$ per protein molecule. We noted that the concentration of $\mathrm{Hg}$ in Semaprochilodus spp. occupying a lower trophic level increased in relation to that in Cichla spp. and B. rousseauxii chain tops, suggesting an increase in $\mathrm{Hg}$ exposure in the food chain when the two collections were compared. However, parvalbumin may prove to be a potential biomarker of this toxic element in aquatic species.

\section{Ubiquitin-40S Ribosomal Protein S27a}

Ubiquitin may be found free or covalently bound to other proteins in the cell cytoplasm [28]. When covalently linked, is conjugated to target proteins through an isopeptide bond and, depending on the lysine residue to which it is bound, the complex has different functions such as DNA repair, degradation of endoplasmic reticulum, cell cycle regulation, lysosomal degradation, protein degradation by the proteasome, endocytotic responses, DNA damage, and processes that lead to the activation of the transcription factor NF- $\mathrm{KB}$ [29]. Furthermore, it is a metalloprotein that has zinc-binding domains, for this element is similar to $\mathrm{Hg}$; this protein can bind to $\mathrm{Hg}$ as well as other divalent metals, such as copper and cadmium. This protein was found in the JL5 spot, where $\mathrm{Hg}$ was also detected. The stoichiometric ratio was $2 \mathrm{Hg}$ atoms per protein molecules, suggesting a protein-metal interaction. Previous studies characterized ubiquitin, a $40 \mathrm{~S}$ ribosomal protein (S27a) found in muscle tissue from other species of Amazon fish (Cichla spp. and B. rousseauxii) $[7,17]$. This protein contains $1-2 \mathrm{Hg}$ atoms per molecule of protein in Cichla spp. and B. rousseauxii, respectively [7, 17]. $\mathrm{Hg}$ was found only in the liver tissue of Semaprochilodus spp. and in the muscle tissue of Cichla spp. and B. rousseauxii. Therefore, further investigation will be necessary to generate more conclusive data on a possible biomarker of $\mathrm{Hg}$ exposure.

\section{Keratin, Type II Cytoskeletal 8}

Keratin, type II cytoskeletal 8, also known as cytokeratin-8, presents in its structure leucine, arginine, isoleucine, carboxylic groups, and an amino terminus that can act as a ligand for divalent metals. In jaraqui, the spot showed approximately 3 JL6 $\mathrm{Hg}$ atoms per protein molecule. Similar results were found in fish Cichla spp. of the Madeira River, where keratin, type II cytoskeletal 8 was found in the liver linked to $\mathrm{Hg}$ [17]. In that study, the stoichiometric ratio was approximately $2 \mathrm{Hg}$ atoms per protein molecule [17]. The history of this protein's binding to $\mathrm{Hg}$ in liver tissue environments of fish species containing $\mathrm{Hg}$ may make it a potential biomarker of this element in fish.

\section{S Ribosomal Protein L36 Mitochondrial}

The 39S ribosomal protein L36 mediates mitochondrial protein synthesis of other proteins within the mitochondria and has been found bound to $\mathrm{Hg}$ in liver tissue of the Amazon fish $B$. rousseauxii in previous studies [7]. In B. rousseauxii, the stoichiometric ratio indicated approximately $2 \mathrm{Hg}$ atoms per molecule of protein, whereas in Semaprochilodus spp., the ratio was no more than 1 to 1 . This can be explained by the jaraqui occupying a lower trophic level than $B$. rousseauxii and thus providing lower amounts of $\mathrm{Hg}$ bioaccumulated in 
the body, since the bioaccumulative process follows the trophic levels [6]. Although the 39S ribosomal protein L36 mitochondrial is present in its terminal chain nitrogen atoms, its binding to mercury/nitrogen is considered weak; however, its occurrence may lead to irreversible conformational damage to the protein $[30,31]$. The ratio of $\mathrm{Hg}$ to $39 \mathrm{~S}$ ribosomal protein L36 mitochondrial found in two species of fish of the Madeira River could lead this protein to become a reliable biomarker of exposure of this toxic element in aquatic animals.

\section{Conclusion}

The technique of protein separation using 2D-PAGE was successful, with gels with clear and intense spots, which facilitated the analysis of $\mathrm{Hg}$ by graphite furnace atomic absorption spectrometry and the characterization of proteins by ESI-MS/MS. The study characterized three proteins in muscle tissue (hemoglobin subunit beta, hemoglobin subunit beta-A/ $\mathrm{B}$, and parvalbumin beta) and five proteins in hepatic tissue (parvalbumin beta parvalbumin-2, ubiquitin-40S ribosomal protein S27a, keratin, type II cytoskeletal 8, 39S ribosomal protein L36, mitochondrial). These proteins represent potential candidates for mercury exposure biomarkers in fish, because all of them (except hemoglobin subunit beta, which was characterized for the first time in Semaprochilodus spp. Madeira River) were also found in other species of Madeira River fish linked to $\mathrm{Hg}$.

Acknowledgments The authors thank the Brazilian research funding agency ANEEL/ESBR-P\&D: 6631-0001/2012/Contract Jirau 004/2013, São Paulo State Research Foundation (Processes: 2012/24035-5, 2013/21297-1 and 2014/02668-1).

\section{Compliance with Ethical Standards}

Conflict of Interest The authors declare that they have no competing interests.

\section{References}

1. Val J, Muñiz S, Gomà J, Navarro E (2016) Influence of global change-related impacts on the mercury toxicity of freshwater algal communities. Sci Total Environ 540:53-62. doi:10.1016/j. scitotenv.2015.05.042

2. Ramírez-Bajo MJ, de Atauri P, Ortega F, Westerhoff HV, Gelpi JL, Centelles JJ, Cascante M (2014) Effects of cadmium and mercury on the upper part of skeletal muscle glycolysis in mice. PLoS One 9:e80018. doi:10.1371/journal.pone.0080018

3. Crump KL, Trudeau VL (2009) Mercury-induced reproductive impairment in fish. Environ Toxicol Chem 28:895-907. doi:10.1897/ 08-151.1

4. Nevado JJB, Martín-doimeadios RCR, Bernardo FJG, Moreno MJ, Herculano AM, Nascimento JLM, Crespo-López ME (2010)
Mercury in the Tapajós River basin, Brazilian Amazon: a review. Environ Int 36:593-608. doi:10.1016/j.envint.2010.03.011

5. Moraes PM, Santos FA, Padilha CCF, Vieira JCS, Zara LF, Padilha PM (2012) A preliminary and qualitative metallomics study of mercury in the muscle of fish from Amazonas, Brazil. Biol Trace Elem Res 150:195-199. doi:10.1007/s12011-012-9502-x

6. Moraes PM, Santos FA, Cavecci B, Padilha CCF, Vieira JCS, Roldan PS, Padilha PM (2013) GFAAS determination of mercury in muscle samples of fish from Amazon, Brazil. Food Chem 141: 2614-2617. doi:10.1016/j.foodchem.2013.05.008

7. Braga CP, Bittarello AC, Padilha CC, Leite AL, Moraes PM, Buzalaf MA, Zara LF, Padilha PM (2015) Mercury fractionation in dourada (Brachyplatystoma rousseauxii) of the Madeira River in Brazil using metalloproteomic strategies. Talanta 132:239-244. doi:10.1016/j.talanta.2014.09.021

8. Bastos WR, Dórea JG, Bernardi JVE, Lauthartte LC, Mussy MH, Hauser M, Dória CRC, Malm O (2015) Mercury in muscle and brain of catfish from the Madeira River, Amazon, Brazil. Ecotoxicol Environ Saf 118:90-97. doi:10.1016/j.ecoenv.2015.04. 015

9. Ceccatto APS, Testoni MC, Ignácio ARA, Santos-Filho M, Malm M, Díez S (2015) Mercury distribution in organs of fish species and the associated risk in traditional subsistence villagers of the Pantanal wetland. Environ Geochem Health. doi:10.1007/s10653015-9754-4

10. Walters DM, Rosi-Marshall E, Kennedy TA, Cross WF, Baxter CV (2015) Mercury and selenium accumulation in the Colorado River food web, Grand Canyon, USA. Environ Toxicol Chem 34:23852394. doi: $10.1002 /$ etc. 3077

11. Borrell A, Tornero V, Bhattacharjee D, Aguilar A (2015) Trace element accumulation and trophic relationships in aquatic organisms of the Sundarbans mangrove ecosystem (Bangladesh). Sci Total Environ 545-546:414-423. doi:10.1016/j.scitotenv.2015.12. 046

12. Amoli JS, Barin A, Ebrahimi-Rad M, Sadighara P (2011) Cell damage through pentose phosphate pathway in fetus fibroblast cells exposed to methyl mercury. J Appl Toxicol 31:685-689. doi:10. 1002/jat.1628

13. Belyaeva EA, Korotkov SM, Saris NE (2011) In vitro modulation of heavy metal-induced rat liver mitochondria dysfunction: a comparison of copper and mercury with cadmium. J Trace Elem Med Biol 25:S63-S73. doi:10.1016/j.jtemb.2010.10.007

14. Bełdowska M, Falkowska L (2016) Mercury in marine fish, mammals, seabirds, and human hair in the coastal zone of the southern Baltic. Water Air Soil Pollut 227:52. doi:10.1007/s11270-0152735-5

15. Dorea JG (2003) Fish are central in the diet of Amazonian riparians: should we worry about their mercury concentrations? Environ Res 92:232-244. doi:10.1016/S0013-9351(02)00092-0

16. Dos Santos FA, Cavecci B, Vieira JCS, Franzini VP, Santos A, Leite AL, Buzalaf MA, Zara LF, Padilha PM (2015) A metalloproteomics study on the association of mercury with breast milk in samples from lactating women in the Amazon region of Brazil. Arch Environ Contam Toxicol 69:223-229. doi:10.1007/s00244-0150161-8

17. Vieira JCS, Cavecci B, Queiroz JV, Braga CP, Padilha CC, Leite AL, Figueiredo WS, Buzalaf MA, Zara LF, Padilha PM (2015) Determination of the mercury fraction linked to protein of muscle and liver tissue of Tucunare (Cichla spp.) from the Amazon region of Brazil. Arch Environ Contam Toxicol 69:422-430. doi:10.1007/ s00244-015-0160-9

18. Lima PM, Neves RDCF, Dos Santos FA, Pérez CA, Silva MO, Arruda MA, Castro GR, Padilha PM (2010) Analytical approach to the metallomic of Nile tilapia (Oreochromis niloticus) liver tissue by SRXRF and FAAS after 2D-PAGE separation: preliminary results. Talanta 82:1052-1056. doi:10.1016/j.talanta.2010.06.023 
19. Silva A, Neves RCF, Quintero-pinto LG, Padilha CCF (2007) Determination of selenium by GFAAS in slurries of fish feces to estimate the bioavailability of this micronutrient in feed used in pisciculture. Chemosphere 68:1542-1547. doi:10.1016/j. chemosphere.2007.03.003

20. Hauser-Davis RA, Bastos FF, Tuton B, Chávez Rocha R, Saint Pierre T, Ziolli RL, Arruda MA (2014) Bile and liver metallothionein behavior in copper-exposed fish. J Trace Elem Med Biol 28: 70-74. doi:10.1016/j.jtemb.2013.09.003

21. Tomas M, Tinti A, Bofill R, Capdevilla M, Atrian S, Torreggiani A (2016) Comparative Raman study of four plant metallothionein isoforms: insights into their $\mathrm{Zn}$ (II) clusters and protein conformations. J Inorg Biochem 156:55-63. doi:10.1016/j.jinorgbio.2015. 12.027

22. González-Estecha M, Bodas-Pinedo A, Guillén-Pérez JJ et al (2014) Methylmercury exposure in the general population; toxicokinetics; differences by gender, nutritional and genetic factors. Nutr Hosp 30:969-988. doi:10.3305/nh.2014.30.5.7727

23. Pedrero Zayas Z, Ouerdane L, Mounicou S, Lobinski R, Monperrus M, Amouroux D (2014) Hemoglobin as a major binding protein for methylmercury in white-sided dolphin liver. Anal Bioanal Chem 406:1121-1129. doi:10.1007/s00216-013-7274-6

24. Park S, Lee B-K (2013) Body fat percentage and hemoglobin levels are related to blood lead, cadmium, and mercury concentrations in a Korean adult population (KNHANES 2008-2010). Biol Trace Elem Res 151:315-323. doi:10.1007/s12011-012-9566-7
25. Kim BM, Choi AL, Ha EH, Pedersen L, Nielsen F, Weihe P, Hong YC, Jorgensen EB, Grandjean P (2014) Effect of hemoglobin adjustment on the precision of mercury concentrations in maternal and cord blood. Environ Res 132:407-412. doi:10.1016/j.envres.2014. 04.030

26. Elkins KM, Gatzeva-Topalova PZ, Nelson DJ (2001) Molecular dynamics study of $\mathrm{Ca}(2+)$ binding loop variants of parvalbumin with modifications at the "gateway" position. Protein Eng 14: $115-126$

27. Chudinova TV, Belekhova MG, Tostivint H, Ward H, Rio JP, Kenigfest NB (2012) Differences in parvalbumin and calbindin chemospecificity in the centers of the turtle ascending auditory pathway revealed by double immunofluorescence labeling. Brain Res 1473:87-103. doi:10.1016/j.brainres.2012.07.022

28. UniProt (2007) http://www.uniprot.org/uniprot/P68200. Accessed 16 Aug 2017

29. Karsi A, Patterson A, Feng J, Liu Z (2002) Translational machinery of channel catfish: I. A transcriptomic approach to the analysis of $3240 \mathrm{~S}$ ribosomal protein genes and their expression. Gene 291:177-186. doi:10.1016/S0378-1119(02)00595-4

30. Paula MT, Zemolin AP, Vargas AP, Golombieski RM, Loreto EL, Saidelles AP, Picoloto RS, Flores EM, Pereira AB, Rocha JB, Merritt TJ, Franco JL, Posser T (2014) Effects of Hg(II) exposure on MAPK phosphorylation and antioxidant system in D. melanogaster. Environ Toxicol 29:621-630. doi:10.1002/tox.21788

31. Marshall JL, Booth JE, Williams JW (1984) Characterization of the covalent mercury (II)-NADPH complex. J Biol Chem 259: 3033-3036 